\title{
EFFECTS OF ELEVATED TEMPERATURE ON COMPRESSIVE STRENGTH OF CONCRETE: A CASE STUDY OF GRADE 40 CONCRETE
}

\author{
S. O. Osuji ${ }^{1}{ }^{*}$ and U. Ukeme ${ }^{2}$ \\ 1,2 Department of Civil EngineERing, University of BEnin, Benin City, Edo State. NiGERIA \\ E-mailaddresses: ${ }^{1}$ sylvester.osuji@uniben.edu, ${ }^{2}$ uchennaukeme@yahoo.com
}

\begin{abstract}
This study presents the results of investigation of the effects of elevated temperatures on the compressive strength of Grade 40 concrete. A total of thirty cube specimens were cast, cured in water at ambient temperature in the laboratory and subjected to various temperature regimes before testing. $A$ concrete mix of 1:1:3 (cement: fine aggregates: coarse aggregates) with water content ratio of 0.44 , fine aggregates lying in zone 2 of sieve tests as well as granite of maximum size 12.5mmwas designed for these investigations using the Department of Environment Method. Specimens cured for 7 and 28 days were subjected to uniaxial compressive loading tests at room and elevated temperature of 24, 100, 150,200, 250 and 300 degree Celsius at one hour duration. The result indicated $14.49 \%, 25 \%, 51 \%, 35.51 \%$ and $43.88 \%$ decrease in compressive strength at the earlier quoted temperatures respectively. At an elevated temperature of 300 degrees Celsius a peak decrease of $53.47 \%$ in compressive strength was observed.
\end{abstract}

Keywords: ambient temperature; room temperature; elevated temperature; compressive strength; sieve analysis; specific gravity; destructive tests; moisture loss; fire.

\section{INTRODUCTION}

Generally the ambient temperature of concrete structures is expected to be at room values during construction and during their service life. Current design and construction codes take care of safety of these structures in relation to room temperature values [1]. At times the environmental temperature may increase extremely or fluctuate periodically, and often the design strength of the structure is significantly affected [2]. It has become imperative for engineers to be interested in the residual design strength of concrete subjected to high temperatures in order to form data base for performance at these elevated temperatures for practical research applications. Although empirical approaches of applying minimum concrete cover to take care of fire resistance has been the norm [3], a more rational approach arising from statistical evidence is not out of place.

A first step is to subject representative concrete cube mixes to a range of temperature variations above room temperature and observe the change in compressive strength achieved at various concrete ages.
This paper presents the results of concrete cubes tests with respect to variation in residual compressive strength when subjected to temperature ranges from $100^{\circ} \mathrm{C}$ to $300^{\circ} \mathrm{C}$ at interval of $50^{\circ} \mathrm{C}$. Also, the moisture loss of the sample cubes was investigated as well as other minor characterization tests such as sieve analysis and specific gravity was conducted on the fine aggregate.

However, the limitation of this study in terms of temperature range is between $100^{\circ} \mathrm{C}$ to $300^{\circ} \mathrm{C}$ due to available temperature equipment and the concrete grade is of $40 \mathrm{~N} / \mathrm{mm}^{2}$ as lower grades of $25 \mathrm{~N} / \mathrm{mm}^{2}$ and $30 \mathrm{~N} / \mathrm{mm}^{2}$ have been investigated and reported elsewhere [4]. Curing ages are taken at 7 and 28days and the Department of Environment (DOE) mix design approach is used [5].

\section{LITERATURE REVIEW}

From the literature reviewed in this study a number of works has been done on the effect of elevated temperature on pure or partially replaced concrete mixes. 
Due to space limitations, some of the most relevant ones are presented below.

Stress-strain relationship of high strength concrete, HSC, (concrete strength in excess of 70Mpa) has been investigated and reported [6]. The variables considered in the experimental study included concrete strength, type of aggregate, and the addition of steel fibers. Cheng, et al [6] reported that tests show that plain HSC exhibits brittle properties below $600 \mathrm{oC}$, and ductility above $600 \mathrm{oC}$. HSC with steel fibers exhibits ductility for temperatures over $400 \mathrm{oc}$. The compressive strength of HSC decreases by about a quarter of its room temperature strength within the range of $100-400 \mathrm{oC}$. They also showed that surface concrete cracking is a visible type of damage that has significantly adverse effects on the mechanical properties and durability properties of concrete [6].

A study on the identification and quantification of surface cracking of concrete heated to different temperatures ranging from 105 to $1250^{\circ} \mathrm{C}$ was carried out, in addition to the quantification of the residual compressive strengths of concrete after high temperature exposure; both initial surface absorption and total porosity were measured. The study as reported showed that crack density was determined using a flatbed scanner and then images were treated using paint shop program. The total porosity was obtained using American Society for Testing and Materials (ASTM) methods as reported. Further discussions pointed to the fact that the mechanical properties of concrete were largely affected by temperatures beyond $500^{\circ} \mathrm{C}$ and were very feeble when temperatures exceeded $1000^{\circ} \mathrm{C}$. The surface cracks' density, initial surface absorption and total porosity by boiling methods gave a rapid indication on concrete durability from the report [7].

The effect of exposing carbon- fibered reinforced concrete to elevated temperatures on its bond strength with reinforcing steel bars have been investigated and reported [8]. Hassan [8] wrote that experimental program consisting of fabricating and testing of 54 pullout cubic specimens was prepared. From Hassan [8], the specimens were divided into three groups to study the effect of addition of various amounts of discrete carbon fibre on its residual bond strength and the bond strength- slip response after exposure to temperature levels of $150^{\circ} \mathrm{C}, 250^{\circ} \mathrm{C}, 350^{\circ} \mathrm{C}, 450^{\circ} \mathrm{C}$ and $550^{\circ} \mathrm{C}$ in addition to the room temperature. The carbon fibre content considered was $0.0 \%, 0.75 \%$ and $1.0 \%$ by weight of cement. In addition to the pull- out specimens, nine cubes having the same pull-out specimens' size (three from each concrete group mix) were tested in compression. It was concluded that the percentage residual bond strength after exposure to temperature level of $550 \mathrm{oC}$ for the concrete reinforced with $0.75 \%$ carbon fiber by weight of cement (28\%) is lower than that for plain concrete and the concrete reinforced with $1.0 \%$ carbon fibers which are the same (32\%). There was no clear conclusion that could be obtained concerning the effect of changing temperature levels on bond- slip response of plain concrete and that reinforced with $0.75 \%$ and $1.0 \%$ carbon fibers [8].

An experimental investigation was conducted to evaluate the influence of elevated temperatures on the mechanical properties, phase composition and microstructure of silica flour concrete [9]. The blended cement used in this investigation consists of ordinary Portland cement (OPC) and silica flour. The OPC were partially replaced by $0,5,10,15$ and $20 \%$ of silica flour. The blended concrete paste was prepared using the water-binder ratio of $0.5 \mathrm{wt} \%$ of blended cement. The fresh concrete pastes were first cured at $100 \%$ relative humidity for 24 hours and then cured in water for 28 days. The hardened concrete was thermally treated at $100,200,400,600$ and 800 oC for 2 hours. The compressive strength, indirect tensile strength, phase composition and microstructure of silica flour concrete were compared with those of the pure ordinary Portland concrete. The results showed that the addition of silica flour to OPC improves the performance of the produced blended concrete when exposed to elevated temperatures up to 400oC [9].

The utilization of pozzolanic materials such as fly ash (Fa) and calcined waste crushed clay bricks (CWCCB) as binders in ternary mixtures and the application of sisal fibre as reinforcing agent in ordinary Portland cement (OPC) concrete has received attention in recent years [10]. The compressive performance of four categories of $150 \mathrm{~mm}$ concrete cube specimens were investigated comprising; (1) Control mix consisting of plain OPC concrete of 1:2:4 mix ratio ( one part OPC, two parts fine aggregate and four parts coarse aggregate). (2) Concrete specimens as in (1), but reinforced with $3 \%$ volume fraction of $40 \mathrm{~mm}$ length sisal fibre. (3) Ternary mixtures of OPC, Fa and CWCCB at ratios of $50 \%, 30 \%$ and $20 \%$ of total binders respectively, with same fine, coarse aggregate and sisal fibre content. (4) Ternary mixtures of OPC, Fa and CWCCB at ratios of $50 \%, 20 \%$ and $30 \%$ of total binders respectively, also with same fine, coarse aggregate and sisal fibre content. Water/binder ratio for all mixtures 
was fixed at 0.6. The $150 \mathrm{~mm}$ concrete cube specimens were cured, dried and subjected to varying elevated temperatures of $100,150,200,300,400$ and $600^{\circ} \mathrm{C}$ for exposure duration of 2 hours each. The results revealed that between temperatures of $100^{\circ} \mathrm{C}$ and $600^{\circ} \mathrm{C}$, the ternary concrete specimen with $30 \% \mathrm{Fa}$ and $20 \%$ CWCCB showed good thermal stability but recorded a $24 \%$ reduction in compressive strength at elevated temperatures of $600^{\circ} \mathrm{C}$ compared with all the specimens. The ternary concrete with $30 \% \mathrm{Fa}$ and $20 \%$ CWCCB is recommended for structural elements requiring thermal stability [10].

A study modelled the experimental results of Ehm (1986) and the landersson (1987) on transient thermal creep of concrete specimens, under sustained load, at elevated temperatures and investigated the relevance of transient thermal creep on the behaviour of concrete at elevated temperatures [11]. Numerical investigations were carried out on steady state and transient state models using the 'Finite Element Analysis Programme' (FEAP). The investigations included observing the effect of degraded coefficient of thermal expansion and modulus of elasticity of concrete with and without the inclusion of the effect of transient thermal creep (assumed equivalent to the effect of thermo mechanical strain) on the behaviour of concrete, observing the relevance of the transient thermal creep on the behaviour of concrete and observing the effect of sustained compressive stress on the temperature dependent compressive strength of concrete. The study showed that the model predictions fit the experimental results and confirmed i) the absence of transient thermal creep in steady state specimens, ii) that the coefficient of thermal expansion and modulus of elasticity of concrete are degraded at elevated temperatures, iii) that the coefficients of thermo mechanical strain and free thermal expansion changed respectively at $469 \mathrm{oC}$ and $619 \mathrm{oC}$ and iv) that the critical temperature of concrete decreases with increase in the magnitude of the sustained compressive stress [11].

An investigation presented the results of a study on the effect of polyester fiber reinforcement on the residual compressive strength of normal-strength concretes subjected to sustained elevated temperature [12]. Two different volume fractions of polyester fiber were adopted in the concrete which was subjected to elevated temperatures of $1000 \mathrm{C}, 2000 \mathrm{C}, 3000 \mathrm{C}, 4000$ C, $5000 \mathrm{C}, 6000 \mathrm{C}$, and $8000 \mathrm{C}$, sustained for 2 hours. This involved a total of 72 specimens containing $0 \%$, $0.5 \%$, and $1 \%$ volume fraction of $12 \mathrm{~mm}$ polyester fibers in a $150 \mathrm{~mm}$ concrete cube. For each concrete cube specimen, the test results include the residual compressive strength from destructive mode of assessment with Non Destructive Test results to follow. The test results showed that the addition of polyester fibers will contribute to the increase in the compressive strength depending upon the percentage of fibers present in it. Based on this research, it is observed that there is an increasing trend in the residual compressive strength of the normal strength concrete up to sustained elevated temperature of $4000 \mathrm{C}$ due to the addition of polyester fibers at $0.5 \%$ volume fraction [12].

\section{MATERIALS AND METHODOLOGY}

A number of literature reported (as summarized above) have shown that there is dearth of study reported for high strength concrete with local aggregates in Nigeria subjected to elevated temperature. This knowledge gap is one of the justifications for this study made from fine and coarse aggregates sourced from Benin City, Edo State, Nigeria. Materials applied to this study included the Ordinary Portland Cement (OPC) as aggregate binder, fine and coarse aggregate (granite), $12.5 \mathrm{mmmaximum}$ size, as well as portable water. The Riffler sampling method was used to sample the fine aggregate [13]. Thereafter sieve analysis test was conducted on the fine aggregate as well as specific gravity test for coarse aggregate characterization.

A mix design approach as opposed to prescribed mix, using the Department of Environment recommendations [5] was selected as a standard design procedure and applied to the aggregates to arrive at an acceptable design mix after some trial mixes had been tested. Slump test was conducted to check the workability compliance and finally curing of the cubes in accordance with [14] at 7 and 28 days.

Destructive test of three cubes at each temperature regime and age was performed using the Universal Testing Machine after the samples had been placed in a heating oven for an hour and according to the specifications of [15].

Thereafter the moisture loss as determined by mass measurement before and after heating of samples was obtained.

\section{RESULTS}

A concrete mix design of 1:1:3 that is cement: fine aggregate: coarse aggregate, was used for the characteristic strength corresponding to grade 40 
concrete. Data obtained at 7 and 28 days for the effects of temperature with compressive strength are shown in Tables 1 and 2 respectively while the loss of weight as related to elevated temperature and age, are in Figure 1.
The effect of elevated temperature on the compressive strength at 7 days and 28 days for concrete grade 40 as designed is shown in Figure 2.

Table 1: Compressive strength of concrete at various temperatures ( 7 days C40, OPC, 1:1:3)

\begin{tabular}{|c|c|c|c|c|c|c|c|c|c|c|c|}
\hline Temperature & $\begin{array}{l}\text { Identification } \\
\text { of Specimen }\end{array}$ & $\begin{array}{c}\text { Weight } \\
\text { before } \\
\text { placing } \\
\text { in } \\
\text { electric } \\
\text { Oven } \\
(\mathrm{Kg})\end{array}$ & $\begin{array}{l}\text { Weight } \\
\text { after } \\
\text { placing } \\
\text { in } \\
\text { electric } \\
\text { Oven } \\
\text { (Kg) }\end{array}$ & $\begin{array}{c}\text { Percentage } \\
\text { weight } \\
\text { loss }(\mathrm{Kg})\end{array}$ & $\begin{array}{c}\text { Average } \\
\text { weight } \\
\text { loss } \\
(\mathrm{Kg})\end{array}$ & $\begin{array}{c}\text { Density } \\
\text { of cube } \\
\left(\mathrm{Kg} / \mathrm{m}^{3}\right) \\
\text { (after } \\
\text { heating) }\end{array}$ & $\begin{array}{l}\text { Average } \\
\text { Density } \\
\text { of cube } \\
\left(\mathrm{Kg} / \mathrm{m}^{3}\right)\end{array}$ & $\begin{array}{c}\text { Failure } \\
\text { load } \\
\text { (KN) }\end{array}$ & $\begin{array}{l}\text { Compressive } \\
\text { strength } \\
\text { (Mpa) }\end{array}$ & $\begin{array}{l}\text { Average } \\
\text { compressive } \\
\text { strength } \\
\text { (Mpa) }\end{array}$ & Ref \\
\hline $\begin{array}{l}\text { Reference } \\
\text { Mix } 24^{\circ} \mathrm{C}\end{array}$ & $\begin{array}{l}\text { RJU } 1 \\
\text { RJU } 2 \\
\text { RJU } 3 \\
\end{array}$ & $\begin{array}{l}8.571 \\
8.594 \\
8.581 \\
\end{array}$ & $\begin{array}{l}8.571 \\
8.594 \\
8.581 \\
\end{array}$ & $\begin{array}{l}0 \\
0 \\
0 \\
\end{array}$ & 0 & $\begin{array}{l}2539.56 \\
2546.37 \\
2542.52 \\
\end{array}$ & 2542.82 & $\begin{array}{l}857.5 \\
845.3 \\
844.8 \\
\end{array}$ & $\begin{array}{l}38.2 \\
37.7 \\
36.9 \\
\end{array}$ & 37.6 & 1 \\
\hline $100^{\circ} \mathrm{C}$ & $\begin{array}{l}\mathrm{JU} 11 \\
\mathrm{JU} 12 \\
\mathrm{JU} 13\end{array}$ & $\begin{array}{l}8.592 \\
8.582 \\
8.579 \\
\end{array}$ & $\begin{array}{l}8.507 \\
8.521 \\
8.512 \\
\end{array}$ & $\begin{array}{l}0.99 \\
0.71 \\
0.78 \\
\end{array}$ & 0.83 & $\begin{array}{l}2520.59 \\
2520.59 \\
2520.59\end{array}$ & 2520.59 & $\begin{array}{l}751.5 \\
758.2 \\
755.6 \\
\end{array}$ & $\begin{array}{l}33.4 \\
33.7 \\
33.5 \\
\end{array}$ & 33.53 & 2 \\
\hline $150^{\circ} \mathrm{C}$ & $\begin{array}{l}J U 21 \\
\text { JU } 22 \\
\text { JU } 23\end{array}$ & $\begin{array}{l}8.569 \\
8.591 \\
8.586\end{array}$ & $\begin{array}{l}8.419 \\
8.448 \\
8.443 \\
\end{array}$ & $\begin{array}{l}1.75 \\
1.66 \\
1.67\end{array}$ & 1.69 & $\begin{array}{l}2494.52 \\
2503.11 \\
2501.63\end{array}$ & 2499.75 & $\begin{array}{l}689.8 \\
678.0 \\
677.3\end{array}$ & $\begin{array}{l}30.7 \\
30.1 \\
30.0\end{array}$ & 30.27 & 3 \\
\hline $200^{\circ} \mathrm{C}$ & $\begin{array}{l}\text { JU } 31 \\
\text { JU } 32 \\
\text { JU } 33\end{array}$ & $\begin{array}{l}8.581 \\
8.586 \\
8.579\end{array}$ & $\begin{array}{l}8.392 \\
8.381 \\
8.374\end{array}$ & $\begin{array}{l}2.20 \\
2.39 \\
2.39\end{array}$ & 2.33 & $\begin{array}{l}2486.52 \\
2483.26 \\
2481.19\end{array}$ & 2483.66 & $\begin{array}{l}596.7 \\
598.8 \\
597.8\end{array}$ & $\begin{array}{l}26.5 \\
26.6 \\
26.5\end{array}$ & 26.53 & 4 \\
\hline $250^{\circ} \mathrm{C}$ & $\begin{array}{l}\text { JU } 41 \\
\text { JU } 42 \\
\text { JU } 43\end{array}$ & $\begin{array}{l}8.571 \\
8.582 \\
8.588 \\
\end{array}$ & $\begin{array}{l}8.261 \\
8.144 \\
8.278 \\
\end{array}$ & $\begin{array}{l}3.61 \\
3.94 \\
3.61 \\
\end{array}$ & 3.72 & $\begin{array}{l}2447.70 \\
2413.04 \\
2452.74 \\
\end{array}$ & 2437.83 & $\begin{array}{l}525.3 \\
522.8 \\
523.4 \\
\end{array}$ & $\begin{array}{l}23.3 \\
23.2 \\
23.3 \\
\end{array}$ & 23.27 & 5 \\
\hline $300^{\circ} \mathrm{C}$ & $\begin{array}{l}\text { JU } 51 \\
\text { JU } 52 \\
\text { JU } 53 \\
\end{array}$ & $\begin{array}{l}8.592 \\
8.586 \\
8.573 \\
\end{array}$ & $\begin{array}{l}8.159 \\
8.156 \\
8.143\end{array}$ & $\begin{array}{l}5.04 \\
5.01 \\
5.02\end{array}$ & 5.02 & $\begin{array}{l}2417.48 \\
2416.59 \\
2412.74\end{array}$ & 2415.60 & $\begin{array}{l}445.3 \\
442.6 \\
446.8 \\
\end{array}$ & $\begin{array}{l}19.79 \\
19.60 \\
19.80 \\
\end{array}$ & 19.73 & 6 \\
\hline
\end{tabular}

Table 2: Compressive strength of concrete at various temperatures (28 days, C40, OPC 1:1:3)

\begin{tabular}{|c|c|c|c|c|c|c|c|c|c|c|c|}
\hline Temperature & $\begin{array}{l}\text { Identification } \\
\text { of Specimen }\end{array}$ & $\begin{array}{l}\text { Weight } \\
\text { before } \\
\text { placing } \\
\text { in } \\
\text { electric } \\
\text { Oven } \\
(\mathrm{Kg})\end{array}$ & $\begin{array}{l}\text { Weight } \\
\text { after } \\
\text { placing } \\
\text { in } \\
\text { electric } \\
\text { Oven } \\
(\mathrm{Kg})\end{array}$ & $\begin{array}{c}\text { Percentage } \\
\text { weight } \\
\text { loss }(\mathrm{Kg})\end{array}$ & $\begin{array}{c}\text { Average } \\
\text { weight } \\
\text { loss } \\
(\mathrm{Kg})\end{array}$ & $\begin{array}{c}\text { Density } \\
\text { of cube } \\
\left(\mathrm{Kg} / \mathrm{m}^{3}\right) \\
\text { (after } \\
\text { heating) }\end{array}$ & $\begin{array}{l}\text { Average } \\
\text { Density } \\
\text { of cube } \\
\left(\mathrm{Kg} / \mathrm{m}^{3}\right)\end{array}$ & $\begin{array}{l}\text { Failure } \\
\text { load } \\
\text { (KN) }\end{array}$ & $\begin{array}{c}\text { Compressive } \\
\text { strength } \\
\text { (Mpa) }\end{array}$ & $\begin{array}{l}\text { Average } \\
\text { compressive } \\
\text { strength } \\
\text { (Mpa) }\end{array}$ & Ref \\
\hline \multirow{3}{*}{$\begin{array}{l}\text { Reference } \\
\text { Mix } 24^{\circ} \mathrm{C}\end{array}$} & RJU 1 & 8.586 & 8.586 & 0 & \multirow{3}{*}{0} & 2544.00 & \multirow{3}{*}{2545.88} & 1123.0 & 49.9 & \multirow{3}{*}{49.0} & \multirow{3}{*}{1} \\
\hline & RJU 2 & 8.600 & 8.600 & 0 & & 2548.15 & & 1084.9 & 48.2 & & \\
\hline & RJU 3 & 8.591 & 8.591 & 0 & & 2545.48 & & 1100.1 & 48.8 & & \\
\hline \multirow{3}{*}{$100^{\circ} \mathrm{C}$} & $\mathrm{JU} 11$ & 8.610 & 8.530 & 0.93 & \multirow{3}{*}{0.87} & 2527.41 & \multirow{3}{*}{2526.02} & 954.0 & 42.4 & \multirow{3}{*}{41.9} & \multirow{3}{*}{2} \\
\hline & $\mathrm{JU} 12$ & 8.600 & 8.528 & 0.84 & & 2526.81 & & 933.8 & 41.5 & & \\
\hline & JU 13 & 8.590 & 8.518 & 0.84 & & 2523.85 & & 940.3 & 41.9 & & \\
\hline \multirow{3}{*}{$150^{\circ} \mathrm{C}$} & $\mathrm{JU} 21$ & 8.670 & 8.495 & 2.02 & \multirow{3}{*}{1.80} & 2517.04 & \multirow{3}{*}{2510.13} & 814.5 & 36.2 & \multirow{3}{*}{36.5} & \multirow{3}{*}{3} \\
\hline & $\mathrm{JU} 22$ & 8.610 & 8.495 & 1.34 & & 2517.04 & & 828.0 & 36.8 & & \\
\hline & $\mathrm{JU} 23$ & 8.600 & 8.425 & 2.03 & & 2496.30 & & 819.0 & 36.5 & & \\
\hline \multirow{3}{*}{$200^{\circ} \mathrm{C}$} & $\mathrm{JU} 31$ & 8.615 & 8.411 & 2.37 & \multirow[b]{3}{*}{2.38} & 2492.15 & & 704.3 & 31.3 & \multirow[b]{3}{*}{31.6} & \multirow{3}{*}{4} \\
\hline & $\mathrm{JU} 32$ & 8.621 & 8.415 & 2.39 & & 2493.33 & \multirow[b]{2}{*}{2492.64} & 717.8 & 31.9 & & \\
\hline & JU 33 & 8.618 & 8.412 & 2.39 & & 2492.44 & & 710.4 & 31.5 & & \\
\hline \multirow{3}{*}{$250^{\circ} \mathrm{C}$} & $\mathrm{JU} 41$ & 8.600 & 8.270 & 3.84 & \multirow{3}{*}{3.92} & 2450.37 & \multirow{3}{*}{2450.66} & 616.5 & 27.4 & \multirow{3}{*}{27.5} & \multirow{3}{*}{5} \\
\hline & $\mathrm{JU} 42$ & 8.610 & 8.258 & 4.09 & & 2446.81 & & 614.3 & 27.3 & & \\
\hline & $\mathrm{JU} 43$ & 8.615 & 8.285 & 3.83 & & 2454.81 & & 617.1 & 27.8 & & \\
\hline \multirow{3}{*}{$300^{\circ} \mathrm{C}$} & JU 51 & 8.621 & 8.221 & 4.64 & \multirow{3}{*}{4.67} & 2435.85 & \multirow{3}{*}{2431.21} & 509.3 & 22.6 & \multirow{3}{*}{22.8} & \multirow{3}{*}{6} \\
\hline & JU 52 & 8.591 & 8.189 & 4.68 & & 2426.37 & & 511.8 & 22.7 & & \\
\hline & $\mathrm{JU} 53$ & 8.610 & 8.206 & 4.69 & & 2431.41 & & 516.6 & 23.0 & & \\
\hline
\end{tabular}




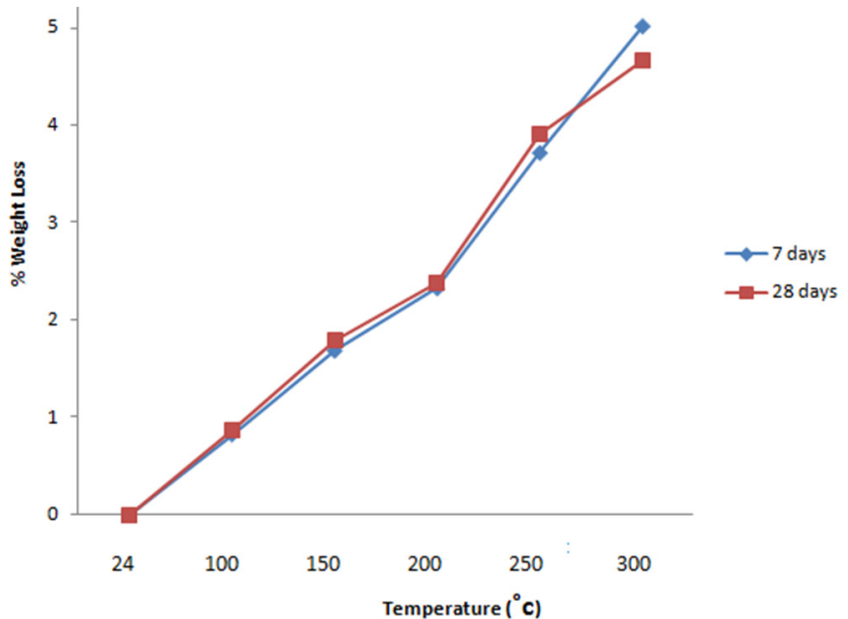

Figure 1: Relationship of weight loss to age of concrete at elevated temperatures ( 7 days, C4O, OPC, 1:1:3)

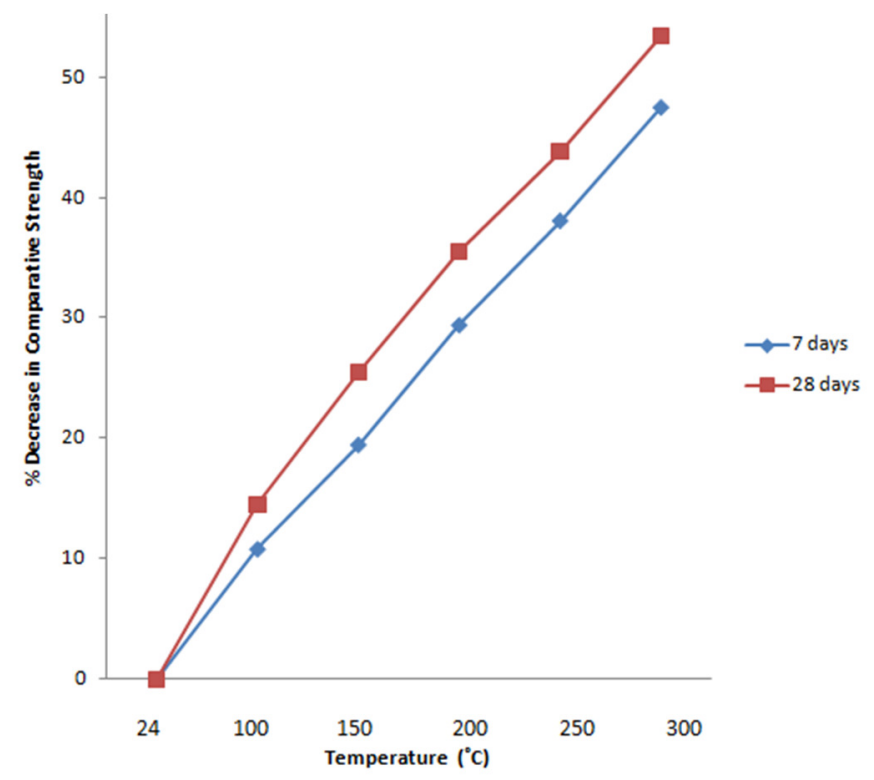

Figure 2: Effect of elevated temperature on concrete compressive strength and age (C40, OPC, 1:1:3)

\section{DISCUSSION}

There was loss of weight as the temperature increased starting from $100^{\circ} \mathrm{C}$ at increments of $50^{\circ} \mathrm{C}$ up to $300^{\circ} \mathrm{C}$, while weight loss increased from 0.87 to $4.67 \%$ as compared to the control mix at room temperature of $24^{\circ} \mathrm{C}$ at 28 days age whereas for 7 days the figures were 0.83 to $5.02 \%$.

But for the same range of temperature at 7 days, the loss of compressive strength was from 10.82 to $47.53 \%$ and at 28 days we had 14.49 to $53.47 \%$. The details are shown in Tables 1 and 2

The reasons for these results may be from the rapid loss of moisture which prevents long term hydration leading to increased strength. Other possible rational for loss of strength is the destruction of active strength generating ingredients such as the cement and aggregates [16]. Another reason postulated for the results experienced in this study is the one given by [2] which shows that the rapidly changing temperature field due to elevated temperature causes rapid changes in stress-strain relationship with that of lower temperatures. Elastic modulus and compressive strength decreases with increased deformation of the concrete material. Cracking and spelling effects are accelerated there by reducing the strength of the concrete at high temperatures [2].

\section{CONCLUSION}

The compressive strength of concrete decreases as temperature increases due to high dehydration of the calcium hydroxide in the cement as well as generating more water vapour thereby leading to strength reduction. Furthermore, loss of moisture reduces the weight as temperature increases.These are known facts from previous investigations [2] and [4]. However the essence of this study is to have a numerical database for Grade 40 concrete which did not form part of the earlier referred works so as to guide the design of concrete elements for this grade. For instance at the recommended design age of 28 days for a concrete grade of 40 investigated loss of strength at $30^{\circ} \mathrm{C}$ of $53.47 \%$ and weight loss of $4.67 \%$ are significant. These points to the fact that more research is need for concrete at elevated temperatures to guide proper design of facilities in places where high temperature applications are needed in areas such as reactor vessels of nuclear facilities and buildings prone to fire accidents.

\section{REFERENCES}

[1] BS 8110 Part 1: Structural use of concrete-code of practice for design and construction"British Standards Institution, London, 1997, p. 24.

[2] Guo, S. and Shi, X.," Experiment and Calculation of Reinforced Concrete at Elevated Temperature." Elsevier Incorporated, Amsterdam, 2011, pp. xiii-xvi, pp 3-16.

[3] Mosley, W.H. and Bungey, J.H.," Reinforced Concrete Design", Fourth Edition, Basingstoke, Macmillan Press Limited, Basingstroke, 1990, p.147.

[4] Izu, H., "Temperature Effects on the Compressive Strength of Grade 30 Concrete", Bachelor of Engineering Project, Civil Engineering Department, University of Benin, Benin City, Nigeria, 2005, pp. xiii and 63.

[5] Jackson, N. and Dhir, R.K.," Civil Engineering Materials", Fourth Edition, Basingstoke: Macmillan Educational Limited, Basingstroke, 1992, p. 206 
[6] Cheng, F.P., Kodur, V.K. and Tien-Chih Wang, T.C. "Stress-strain curves for high strength concrete at elevated temperatures", Journal of Materials in Civil Engineering, Volume 16, Number 1, 2004, p. 1.

[7] Toumi, B and Reishedat, M. "Influence of high temperatures on surface cracking of concrete studied by image scanning technique", Journal of Civil Engineering, Volume 4, Number 2, 2010, p155.

[8] Hassan, S.A. "Effect of elevated temperatures on the bond strength of steel reinforcement and concrete enhanced with discrete carbon fibres", Journal of Engineering and Development, Volume 16, Number 4, 2012, p. 30.

[9] Morsy, M.S., Alsayed, S.H. and Aqel, M. "Effect of elevated temperature on mechanical properties and microstructure of silica flour concrete", International Journal of Civil and Environmental Engineering, Volume 10, Number 01, 2010, p. 1.

[10] Nwankwo, P.O. and Achuenu, E. "Compressive behaviour of sisal fibre reinforced ternary concrete at elevated temperatures ", International Journal of Advancements in Research and Technology, Volume 3, Issue 8, 2014, p. 123.
[11] Folagbade, S.A. "Concrete at elevated temperatures", International Journal of Engineering Research and Applications, Volume 2, Issue 6, 2012, p. 1620.

[12] Suresh, N., Bindiganavile, V and Prabhu, M. "Compressive behaviour of polyester fibre reinforced concrete subjected to sustained elevated temperatures", International Journal of Emerging Technology and Advanced Engineering, Volume 4, Issue 8, 2014, p. 220.

[13] "BS 812: Testing Aggregates- Part 102: Methods for Sampling", British Standards Institution, London, 1989, p.4

[14] Irving, K. "Engineered concrete mix design and test methods", CRC Press, Taylor and Francis Group, Boca Raton, 2010, p. 107.

[15] "BS 1881: Testing Concrete- Part 116: Method for Determination of Compressive Strengths of Concrete Cubes", British Standards Institution, London, 1983, pp.1-3.

[16] Ugbaja, J. U. "Effect of Temperature on the Compressive Strength of Grade 40 Concrete". Bachelor of Engineering Project, Civil Engineering Department, University of Benin, Benin City, Nigeria, 2011, p.57 